\title{
Evaluating an English Course for Master Students in China: A Case of Business English for Accounting Program
}

\author{
Shi Wenjie ${ }^{1, *}$ \\ ${ }^{1}$ School of Foreign Studies, CUFE, Beijing 100081, China \\ *Correspondence: School of Foreign Studies, CUFE, No 39 Xueyuan Nanlu, Haidian District, Beijing 100081, \\ China
}

Received: November 11, 2019

Accepted: December 11, 2019 Online Published: January 11, 2020

doi:10.5430/ijelt.v7n1p31

URL: https://doi.org/10.5430/ijelt.v7n1p31

\begin{abstract}
This study aims to evaluate a business English course for students registered in Master of Professional Accounting or Accountancy (hereafter MPAcc) based on needs analysis of the degree candidates. An online questionnaire, semi-structured interview and classroom observation were used to gain data on the candidates' perception and motivation of learning Business English, learning needs concerning language skills, course contents and course delivery. The results show that the candidates placed importance on learning the language for practical use in business-related domain in general, and for accounting business in particular, and the current in-house business English syllabus has better satisfied the learners need by adopting up-to-date business literature, engaging the learners in discussion. The findings also reveal some issues in designing and teaching courses of English for Specific Purposes (hereafter ESP), including inadequate involvement of accounting specific knowledge in the course contents, lower-than-expected learning outcomes caused by super-large class sizes and limited course availability.
\end{abstract}

Finally, recommendations are given based on the findings as to revise course syllabus and update course arrangement by taking account of the adult language learners' needs pertaining to MPAcc program.

Keywords: business English, needs analysis, master students in accounting

\section{Introduction}

\subsection{English Courses for Master Students in China}

English language education in China's tertiary educational institutions has been under the spotlight from three decades earlier, wherein most of the studies have been focused on the College English Program for undergraduate students working on bachelor degrees (e. g., Cai, 2004; Wang, 2015, Shi, 2018a). The issues of English language teaching for graduate students have been less sufficiently addressed, albeit with a handful of studies on EAP instruction for non-English major graduates in China's context (e. g., Li, 2007; Cargill, O'Connor \& Li, 2012; Wang \& Yang, 2012; Cheng, 2016). But since the transformation of College English Program featured by a shift from EGP-based course structure to ESP/EAP-oriented one was in place in China over one decade ago (Shi, 2018b), the impact of the ongoing reform has rippled into the English language teaching in graduate students for master degrees or above.

In accordance with the Graduate School English Teaching Syllabus for Non-English Majors (1993), the main tasks of English language teaching for master degree or above are to develop degree applicants' language abilities for communication in academic or professional setting by designing language courses focused on academic literacy for the degree candidates. However, the widely varying specific disciplines in which these degree applicants were situated mean there will be more diversified and specified language needs from these EFL learners of master degrees or above. This scenario thus derails the likelihood for universities to implement a unified, one-for-all-disciplines English language course syllabus. Therefore, discipline-specific syllabi for English courses were designed in line with the national syllabus in an attempt to meet the widely varied demands from research master degree students with EAP-featured syllabi (Cheng, 2016), and professional master degree applicants with ESP-focused ones. 
As a consequence, ESP/EAP-based English language courses were designed and administered by universities who offer master degrees in specific disciplines. There was no exception for X University of Finance and Economics, where the vast majority of the master degree candidates are in the disciplines of business and economics, and the master degree programs are available in two categories in terms of study focus: research-oriented and profession-oriented. English for business and economic purposes are required courses for professional master degree applicants, be they registered as full-time or part-time students.

It has been noteworthy that the profession-oriented master degree programs enjoyed rapid expansion over the past decade due to rising demands from the employers and the more practical solution-based teaching models in compacted study periods (Lu, Zhou \& Zhao, 2015), though the professional master degree programs generally entail comparatively higher tuition than research counterparts.

The X University of Finance and Economics offers professional master degree programs in the following disciplines: Business Administration, Professional Accounting, Public Administration, Insurance Master, Law Master, Financial Master, etc., which underwent rapid expansion and share the half of the total of master degree students to date, equaling the number of research master degree students in annual enrollment from 2017 (see http://gs.cufe.edu.cn/bmgk/yjsjygs.htm).

The MPAcc program offered by the university has been widely recognized among applicants and employers due to the strong employability acquired by graduates and excellent professional performance displayed by these degree holders, thus securing a place in the program has been highly competitive, for which the applicants will go through a nation-wide Graduate Entrance Exams, school-level disciplinary exams and interviews before being shortlisted for admission to the program.

The MPAcc program highlights promoting international vision for students, which was embodied in the syllabus of the program that offer intensive business English course, regular guest talks from international accounting firms or other business fields (see http://soa.cufe.edu.cn/jz/index.htm), exchange program with overseas institutions and partnership with internationally recognized accounting training and certification agencies like ACCA in the U.K, IMA in the U.S (Meng, Yuan, Liu \& Zhu, 2013).

\subsection{Business English for MPAcc Degree Candidates}

In accordance with the Guiding Syllabus for MPAcc in China (2014) by National MPAcc Teaching Steering Committee (henceforth Guiding Syllabus), the aims of MPAcc program with regard to international vision and foreign language competency were stated as follows:

"the primary aim of the program is to prepare accounting professionals for having international vision, which is essential for accounting and managerial positions in advanced levels...the master degree candidates are expected to have a proficient command of a foreign language and use it in workplace with ease and fluency" .

To make the aim achieved, the Guiding Syllabus (2014) prescribes that the course of foreign language will be provided by the educational institutions in compulsory and non-compulsory modules, where compulsory course having a weight of three credits, non-compulsory with a weight of two credits out of a total of forty credits required for the eligibility of applying for degree. When it comes to university-level course structure, the universities are expected to provide foreign language course aligned with the universities' disciplinary strengths in researching and teaching. Thus, university-level syllabi will be drafted and administered among different universities to address the learning needs of the degree candidates as well as highlight their academic excellence and priority.

\subsubsection{Course Syllabus Design}

Business English is a recognized branch of English for Specific Purposes in the domain of TEFL (Hutchinson and Waters, 1987: 17), and needs analysis for this learning-centered approach is an integral part for syllabus writing (Jordan, 1984; Edwards, 2000; Taillefer, 2007; Serafini et al, 2015). Business English in China has gone through some changes from earlier intuition or material-led independent course to a vibrant and research-led discipline and is gaining wide academic attention in China (Zhang, 2007; Bargiela-Chiappini \& Zhang, 2013; Cheng \& Anthony, 2014).

The School of Accountancy is in charge of providing in-house syllabi and teaching operation for MPAcc degree in X University of Finance and Economics. In light of the Guiding Syllabus, the School of Accountancy commissioned language teachers from the School of Foreign Studies in the XUFE to build teaching team, survey learners' needs, compile teaching materials and deliver the courses of foreign languages to the degree candidates.

Thereafter, needs analysis of the degree candidates and consultation with subject teachers in the discipline of 
accountancy were conducted before a course syllabus of business English for accounting purposes was devised and provided for the MPAcc program.

The aims and outcomes of the courses are to help would-be MPAcc degree holders equipped with intermediate levels of business English for accounting purposes, with intercultural communicative awareness in international business setting, with acute awareness of the essential vocabulary in accounting and continued motive to update individual knowledge through the medium of English by lifelong learning.

The teaching will be primarily conducted by language teachers in the form of lectures and workshops by using textbook of English in accounting and finance and adapting up-to-date business texts from business and finance section of news websites in English.

The assessment will be administered through in-class group projects of presentation on business-related topics, after-class assignments of reading and end-of-course exam.

\subsubsection{Course Delivery}

In light of the time constraints of the program and teaching arrangement, the business English was offered only in the compulsory module lasting for nine weeks with four hours of classroom instruction in each session every week. For those degree applicants who are part-time students, the courses were scheduled on weekends, namely morning, afternoon or evening sessions. The class size has been huge in terms of students' number that ranges from thirty to ninety, which might affect teaching interactively.

The students who apply for the part-time MPAcc program and register in the business English for accounting purposes are mainly intermediate Chinese EFL learners who have obtained their bachelor degrees for at least three years before applying for master degree program. They have several years of working experience in accounting positions primarily in a Chinese language-medium environment with less exposure to foreign languages, despite the fact that only few of them work in foreign or joint-venture companies where English is required.

In addition to business English in the compulsory modules, the School of Accountancy provides regular lectures for students that are given by accounting specialists from the well-known international accounting firms and educational agency of accounting, sometimes by native English-speakers delivered in English language, which are believed to be an effective way for students to follow the latest development in accounting practice internationally.

\subsection{Research Questions}

As an essential way to improve the candidates' English language proficiency, we devised a standardized procedure for English course design and assessment to guarantee high-quality courses based on learners' needs, subject faculty expectation and professional experts' feed-backs.

This study is a post-course evaluation of students' satisfaction, further expectation and suggestions for the course delivered to them in the first term, a nine-week intensive business English.

The researcher intends to look at the following research questions through questionnaire, interview and classroom observation:

1). How business English is perceived and rated by these master degree candidates?

2). What are their specific needs, wants and lacks in terms of language skills and course contents?

3). In what aspects can the course be adapted to accommodate the learners' needs?

\section{Method}

\subsection{Sampling Procedures}

The study was conducted in the year of 2015 as an end-of-course review of the business English delivered for the MPAcc candidates who were enrolled in the year of 2014 or earlier, among whom 143 respondents completed the on-line questionnaire and 20 of them were randomly sampled for interview in the condition of anonymity. Prior questionnaires have been trialed over preceding years with other cohort of students, which turned to be of fair reliability and validity.

As part of teaching quality assurance, the School of Accountancy administers end-of-course evaluation in the courses upon having been delivered to MPAcc candidates regarding course syllabus, teaching contents, teaching methods and up-to-date teaching with cases etc. In the similar vein, business English course review is conducted by teachers at the end of the course to collect students' feedback to the course on learner's needs and expectation to the course syllabus 
and course delivery.

\subsection{Participant Characteristics}

The MPAcc program offered in XUFE were registered by full-time and part-time candidates, in which full-time candidates are residential students on campus to receive weekday tutorial sessions and workshops, while the part-time candidates are working on weekdays and coming to school for courses and workshops. Part-time MPAcc applicants are required to have at least three years of work experience in accounting-related occupations before they apply for the degree program, whereas for full-time MPAcc program applicants, currently there is no requirement on minimum years of work experience. In addition, full-time candidates are different from part-time ones in that the full time candidates will be qualified for master degree and diploma on the conditions that they have met the requirements for degree and diploma, while part-time candidates are only conferred with master degree without diploma on the condition that they have met the requirements for the part-time MPAcc program. Of all the 143 candidates who participated the online investigation, 85 of them were full-time candidates and 58 part-time candidates. Table 1 presents a summary of the demographic features of the respondents to the online questionnaire, which shows that the ratio of full-time MPAcc candidates (59.4\%) vs. part-time candidates (40.6\%), closely representing the annual enrollment ration of full-time students against part-time ones (60\% vs. $40 \%)$.

Table 1. Demographic Profile of Respondents

\begin{tabular}{|c|c|c|c|}
\hline \multicolumn{4}{|c|}{ Profile of respondents for online questionnaire $(\mathrm{N}=143)$} \\
\hline $\begin{array}{c}\text { Full or } \\
\text { part-time }\end{array}$ & $\begin{array}{l}\text { Number of } \\
\text { respondents }\end{array}$ & $\%$ of total & Major features of respondents \\
\hline Full-time & 85 & 59.4 & $\begin{array}{l}\text { No prior work experience required for most of them; They are } \\
\text { expected to be conferred master degree and diploma by graduation. }\end{array}$ \\
\hline Part-time & 58 & 40.6 & $\begin{array}{l}\text { Prior work experience is mandatory; They will be conferred with } \\
\text { only master degree. }\end{array}$ \\
\hline
\end{tabular}

\subsection{Data Collection and Analysis}

The data from the online questionnaire and interviews were collected, coded and analyzed by business English teaching team through descriptive statistical analysis and qualitative protocol analysis with regards to the perceived importance of the business English, their needs and wants related to their current or future job positions, the delivery of the business English.

\section{Results}

\subsection{Self-perceived Importance of and Motivation for Business English}

Self-perceived importance and motivation for business English course were investigated to look into the attitudes and motivations held by those candidates of MPAcc program. The findings show that these respondents attached high importance to business English and they learned the course mainly for credit requirement embedded in the program and for securing a better job upon graduation.

Table 2. The Importance of Business English in MPAcc Program

\begin{tabular}{lcccc}
\hline \multicolumn{3}{c}{ Rating of the perceived importance of business English in MPAcc Program and for career development. $(\mathrm{N}=143)$} \\
\cline { 2 - 5 } Options & \multicolumn{2}{c}{ In current master program } & $\%$ & For future career development \\
\cline { 2 - 5 } & Respondents & 50.35 & Respondents & $\%$ \\
\hline Very important & 72 & 34.97 & 71 & 49.65 \\
Important & 50 & 11.19 & 12 & 37.76 \\
Neutral & 16 & 0.7 & 2 & 8.39 \\
Less important & 1 & 2.8 & 4 & 1.40 \\
Not important & 4 & & & 2.80 \\
\hline
\end{tabular}


Table 2. indicates that the vast majority of the respondents (over $85 \%$ ) deemed that the business English was important or very important for MPAcc program and future career development, and that a tiny fraction of those surveyed (under 5\%) believed business English was less important or not important.

\subsection{Motivations for Language Learning in Master Program}

With regard to the motivations for learning English language in pursuit of master degree, the top three motivations, as indicated in Table 3., were securing for a better job (AR: 2.03), mandatory credit in the language course (AR: 2.76) and linguistic and cultural literacy (AR: 3.31 ) to be acquired from the course. The calculation implies that the smaller AR values predict higher motivation. The motivation rankings shown by these respondents imply that the EFL learners of master students in China have explicit instrumental motivations in learning a foreign language, either for securing a better job in the job market, or for earning the credits attached to foreign language courses and required by the syllabus. They also demonstrated integrative motivation attached to foreign language learning as being linguistically and culturally literate can be interpreted as an integrative motivation for those respondents. They expect to know more about target language and culture through the language courses, relating to the foreign culture in general and business activities and cultures in particular.

Table 3. The Motivations for Learning English Language

\begin{tabular}{|c|c|c|c|c|c|c|c|c|}
\hline \multicolumn{9}{|c|}{ Ranking of motivations for learning English in master degree program by priority $(\mathrm{N}=143)$} \\
\hline \multirow[t]{2}{*}{ Principal Motivations } & \multicolumn{8}{|c|}{$\begin{array}{l}\text { Percentage of respondents who rank motivations by priority on serial } \\
\text { numbers from } 1^{\text {st }} \text { to } 7^{\text {th }}\end{array}$} \\
\hline & $1^{\text {st }}$ & $2^{\text {nd }}$ & $3^{\text {rd }}$ & $4^{\text {th }}$ & $5^{\text {th }}$ & $6^{\text {th }}$ & $7^{\text {th }}$ & $\begin{array}{l}\text { Averaged } \\
\text { Ranking (note 1) }\end{array}$ \\
\hline For credits & $23.78 \%$ & $25.17 \%$ & $20.98 \%$ & $17.48 \%$ & $6.29 \%$ & $6.29 \%$ & $0.0 \%$ & 2.76 \\
\hline For securing better jobs & $44.06 \%$ & $27.27 \%$ & $16.08 \%$ & $9.09 \%$ & $2.1 \%$ & $0.7 \%$ & $0.7 \%$ & 2.03 \\
\hline For studying abroad & $6.29 \%$ & $4.9 \%$ & $12.59 \%$ & $19.58 \%$ & $29.37 \%$ & $22.38 \%$ & $4.9 \%$ & 4.48 \\
\hline For passing CET-4/6 (note 2) & $1.4 \%$ & $9.79 \%$ & $16.78 \%$ & $16.78 \%$ & $25.17 \%$ & $26.57 \%$ & $3.5 \%$ & 4.48 \\
\hline For personal interest & $9.79 \%$ & $9.09 \%$ & $12.59 \%$ & $22.38 \%$ & $21.68 \%$ & $23.08 \%$ & $1.4 \%$ & 4.12 \\
\hline $\begin{array}{l}\text { For linguistic and cultural } \\
\text { literacy }\end{array}$ & $14.69 \%$ & $23.78 \%$ & $20.28 \%$ & $13.29 \%$ & $12.59 \%$ & $15.38 \%$ & $0.0 \%$ & 3.31 \\
\hline Others & $0.0 \%$ & $0.0 \%$ & $0.7 \%$ & $1.4 \%$ & $2.8 \%$ & $5.59 \%$ & $89.51 \%$ & 6.82 \\
\hline
\end{tabular}

Notes: the aggregate percentile vertical or horizontal values may not be exactly 1 due to the rounding off based on two decimal places.

\subsection{Satisfaction to the Business English Course}

Researcher looked at the satisfaction rating of these MPAcc candidates to the business English in terms of satisfaction with overall instruction in general, and with course arrangement, teaching materials used and teaching styles adopted by teachers in particular. Among the four dimensions being analyzed, the satisfaction to overall instruction, course arrangement, teaching style and teaching materials were rated $76.9 \%, 58.8 \%, 79.1 \%, 72.7 \%$ respectively, with the satisfaction to course arrangement noticeably lower than other three factors. The follow-up interview with the respondents showed that the students were better satisfied with the business English course in the MPAcc program regarding teaching materials, teaching styles and methods. But they complained about course arrangement on the grounds that the class sizes were too large to have efficient interaction among students and teachers, and the instruction hours for each session comprising 4 hours were long and made them tired, and the business English was arranged only in one term, which was deemed unhelpful for long-term learning. 
Table 4. Overall Satisfactions to the Current Business English

\begin{tabular}{lcccccccc}
\hline \multicolumn{7}{c}{ Rating on satisfactions to the current Business English in MPAcc Program (N=143) } \\
\hline & Overall delivery & Course arrangement & Teaching methods & \multicolumn{2}{c}{ Teaching materials } \\
\hline Options & Number & $\%$ & Number & $\%$ & Number & $\%$ & Number & $\%$ \\
\hline Very Satisfied & 49 & 34.2 & 26 & 18.2 & 43 & 30.1 & 32 & 22.4 \\
Satisfied & 61 & 42.7 & 58 & 40.6 & 70 & 49 & 72 & 50.3 \\
Neutral & 28 & 19.6 & 51 & 35.7 & 28 & 19.6 & 34 & 23.8 \\
Less Satisfied & 4 & 2.8 & 6 & 4.2 & 1 & 0.7 & 4 & 2.8 \\
Not Satisfied & 1 & 0.7 & 2 & 1.4 & 1 & 0.7 & 1 & 0.7 \\
\hline
\end{tabular}

\subsection{Perceived Learning Needs and Wants}

The wants and needs of MPAcc candidates were surveyed and discussed, as were indicated in Table 5 and 6 , in which more than one option was allowed. The fact that Chinese EFL learners are weak at, and in need of immediate improvement in productive language skills was ascertained by the findings in this research, which has been echoed by previous studies (Shi, 2018a). But for the cohort of respondents in this study, speaking is noticeably placed in a more needed language skill than writing on the basis of their self-evaluation of language skills needs and proficiency.

\subsubsection{Self-perceived Language Skills of being Wanted and Commanded}

Table 5. Self-evaluation of Language Skills

\begin{tabular}{lcccc}
\hline & \multicolumn{3}{c}{ Rating on self-identified language skills of being wanted and fairly commanded (N=143) } \\
\hline \multirow{2}{*}{ Options } & \multicolumn{2}{c}{ Language skills being wanted } & \multicolumn{2}{c}{ Language skills of being commanded } \\
\cline { 2 - 5 } & Number & 62.9 & Number & $\%$ \\
\hline Listening & 90 & 81.8 & 22 & 15.4 \\
Speaking & 117 & 14 & 17 & 11.9 \\
Reading & 20 & 34.3 & 117 & 81.8 \\
Writing & 49 & 16.8 & 19 & 13.3 \\
Translating & 24 & 28 & 19.6 \\
\hline
\end{tabular}

As for wants in language skills, speaking and listening skills were regarded as two language skills that are the most wanted for the respondents, while reading and translation skills were considered as the least wanted skills; In terms of the rating of fairly commanded language skills, they rated reading skill as the best commanded skill, followed by translating, listening, writing and speaking skills, which were notably lower than reading.

These findings indicated that speaking and listening skills were immediately needed and wanted by these learners, and these skills were the least commanded skills as well. Conversely, reading skill was fairly commanded by these learners with least degree of wants in their language learning needs. The language skills of translating and writing were not rated as immediately needed skills, and were not rated as fairly commanded ones either.

\subsubsection{Expected Teaching Contents in Business English}


Table 6. Expectation of Teaching Content Relevance

\begin{tabular}{|c|c|c|c|c|c|c|c|}
\hline \multicolumn{8}{|c|}{ Ranking of expected teaching content relevance in business English by priority (N=143) } \\
\hline \multirow[b]{2}{*}{ Interested contents } & \multicolumn{6}{|c|}{$\begin{array}{l}\text { Percentage of respondents who rank interested content by priority on } \\
\text { serial numbers from } 1^{\text {st }} \text { to } 6^{\text {th }}\end{array}$} & \multirow[b]{2}{*}{ Averaged Ranking } \\
\hline & $1 \mathrm{st}$ & 2nd & $3 \mathrm{rd}$ & 4th & 5 th & 6 th & \\
\hline Exam-taking skills & $20.98 \%$ & $13.99 \%$ & $12.59 \%$ & $23.08 \%$ & $28.67 \%$ & $0.7 \%$ & 3.27 \\
\hline Specific disciplines & $33.57 \%$ & $22.38 \%$ & $25.17 \%$ & $13.99 \%$ & $3.5 \%$ & $1.4 \%$ & 2.36 \\
\hline $\begin{array}{l}\text { Language skills (e.g. writing } \\
\& \text { speaking) }\end{array}$ & $23.08 \%$ & $27.97 \%$ & $17.48 \%$ & $21.68 \%$ & $8.39 \%$ & $1.4 \%$ & 2.69 \\
\hline Future business \& occupation & $12.59 \%$ & $23.78 \%$ & $30.77 \%$ & $21.68 \%$ & $9.79 \%$ & $1.4 \%$ & 2.97 \\
\hline Inter-cultural literacy & $9.79 \%$ & $11.19 \%$ & $13.99 \%$ & $18.88 \%$ & $45.45 \%$ & $0.7 \%$ & 3.81 \\
\hline Others & $0.0 \%$ & $0.7 \%$ & $0.0 \%$ & $0.7 \%$ & $4.2 \%$ & $94.41 \%$ & 5.92 \\
\hline
\end{tabular}

Notes: the aggregated percentile vertical or horizontal values may not be exactly 1 due to the rounding off of two decimal places.

In terms of their learning expectations regarding teaching contents, the top three options from the questionnaire were language in specific discipline (AR: 2.36), advanced language skills (AR: 2.69) and future business and occupation related teaching contents (AR: 2.97). The same calculation was applied as in Table 3, smaller AR values indicate higher expectations to the teaching contents. So far, by integrating the needs concerning language skills with the expectations on teaching contents, the researcher concluded that these respondents expected that the business English courses gave more priority to speaking and listening skills training related to accounting and management discipline that will be applicable to their future workplace.

3.4.3 Expected Teaching Focus of Language Skills in Business English

Table 7. Expectation on Teaching Focus Concerning Language Skills or Knowledge

\begin{tabular}{|c|c|c|c|c|c|c|}
\hline \multicolumn{7}{|c|}{ Ranking of teaching focus concerning language skills or knowledge from business English by priority $(\mathrm{N}=143)$} \\
\hline & \multicolumn{5}{|c|}{$\begin{array}{l}\text { Percentage of respondents who rank teaching focus by priority on serial } \\
\text { numbers from } 1^{\text {st }} \text { to } 5^{\text {th }}\end{array}$} & \multirow[b]{2}{*}{$\begin{array}{l}\text { Averagec } \\
\text { Ranking }\end{array}$} \\
\hline Skills or knowledge & $1 \mathrm{st}$ & 2nd & $3 \mathrm{rd}$ & 4 th & 5 th & \\
\hline Pronunciation accuracy & $32.17 \%$ & $23.08 \%$ & $24.48 \%$ & $11.89 \%$ & $8.39 \%$ & 2.41 \\
\hline Listening & $20.98 \%$ & $30.77 \%$ & $22.38 \%$ & $18.88 \%$ & $6.99 \%$ & 2.6 \\
\hline Speaking & $30.07 \%$ & $30.77 \%$ & $25.17 \%$ & $13.29 \%$ & $0.7 \%$ & 2.24 \\
\hline Writing & $11.19 \%$ & $8.39 \%$ & $6.99 \%$ & $41.26 \%$ & $32.17 \%$ & 3.75 \\
\hline Translation and interpretation & $5.59 \%$ & $6.99 \%$ & $20.98 \%$ & $14.69 \%$ & $51.75 \%$ & 4.0 \\
\hline
\end{tabular}

As for expected teaching focus in language skills or knowledge from the business English course, Table 7 indicates that the respondents attached significant importance to speaking (AR: 2.24) and listening (AR: 2.6) skills, particularly to pronunciation accuracy (AR: 2.41), wherein the smaller values of AR predict higher expectations from respondents on related skills or knowledge. The follow-up interview indicated that these respondents were not good at speaking and oral communication even though they have learned the language for more than fifteen years, starting from when they sat in primary school till now they are studying English in graduate school. One interviewee admitted that:

“... in workplace those co-workers who have proficient speaking and oral commutation abilities are more likely to be engaged in international business or cross-cultural business activities that will more likely lead to staff career upward mobility..."

So they came to realize that learning English by giving priority to speaking skills would help them build up 
confidence in communicating with foreign business partners and bring about wider job prospective. This can be supported by similar conclusion that improved communicative abilities in English gave rise to more business opportunities (Ku \& Zussman, 2010).

With regard to the pressing concerns in the current business English courses, they shared their concerns on course arrangement, teachers' limited disciplinary expertise, super large class sizes, wide disparity among different students in language proficiency, limited course repertory and teaching resources.

Meanwhile, they mentioned their inadequate time input to language learning as one key reason for not having achieved expected outcomes. They also suggested that language class should be delivered by native English teachers in collaboration with English language teachers of Chinese nationality, which will make the course delivery rich in different activities, teaching contents and styles.

They acknowledged that the business English course provided them with an opportunity to learn the language by using it in classroom, but the teaching styles used in the classroom were described as follows by one interviewee:

"Teaching is as traditional as in high school, featured by lecturer teaching and students memorizing the complicated technical vocabulary."

They thus expected that the case method of teaching be adopted in the classroom, and that teaching materials be more frequently updated with accounting business related cases.

\section{Discussion}

The current business English embedded in the MPAcc program have better met the candidates' specified and diversified needs-if at all, there are, however, issues that need to be given due attention in the course updates and delivery that will follow.

First, for students' motivation and learning needs in business English, the MPAcc candidates attached considerable importance to English language course for future academic and career development, and they gave priority to productive language skills in business and disciplinary fields, particularly speaking and oral communicative abilities in accounting related topics. Thus, the course content and arrangement need to be closely attuned to their needs for oral communication-focused tasks, the classroom atmosphere needs to be more communication friendly, which, however, pose challenges to the current course arrangement.

Second, as for the current course arrangement, the MPAcc teaching administration in the School of Accountancy gives too much priority to the cost-efficient program administration, even at the expense of undermining learning effectiveness in language classroom. Consequently, a total of 90 full-time students, or a minimum number of 35 part-time students were placed in one class to have business English course. It will be incredibly difficult for language teachers to organize classroom activities through interaction-focused case approach, as was echoed by previous study on the impact of class size (Lee, 2009). In addition, arranging 4 hours in a row for business English in one session given by one teacher is challenging for learners and instructors, unavoidably leading to mental exhaust and physical fatigue for both teachers and students, which will compromise the learning and teaching effectiveness, whatever teaching passion or learning motivation were dedicated by teachers or students.

From the value-for-money perspective, MPAcc candidates pay higher tuition for the degree program, looking for high quality courses in their fields, where English is no exception and they ideally deemed that there should be more courses on business English available to students at varied language proficiency levels. The courses should be scheduled in students-friendly time slots in different academic terms so that they can choose based on their time and proficiency level.

Third, the students surveyed note the gap between their non-sustained personal input in language learning efforts and higher expectation on learning outcomes, realizing that command of language skills requires continued efforts and time commitment. Time constraints inherent for most part-time students who work on weekdays and sit in MPAcc courses on weekends, as well as inadequate exposure to English-language-medium workplace were considered main reasons. For those few students with higher English language proficiency, they believed that the current business English course failed to meet their learning needs and expectations on the grounds that the teaching contents and classroom activities were fit for the vast majority of those students with relatively lower language proficiency levels.

Therefore, to solve these problems, the researcher suggests that a placement test will be introduced to divide the students into three levels based on their performance in the placement test, and smaller class sizes seating less than 30 students need to be administrated, and a flexible timetables will be offered for students to choose to fit their time 
and proficiency.

Forth, for business English teachers with no academic expertise in business education, teaching business-related topics for MPAcc candidates will be of challenge in terms selecting and utilizing teaching materials, arranging topics for classroom activities, discussing business and accounting related issues in specific disciplines, which resonated with previous ESP research findings (Wu \& Badger, 2009; Tao \& Gao, 2018).

Consequently, the researcher recommends that business English teachers should be expanded beyond language teachers within linguistic disciplines, inviting subject faculty with excellent English language abilities and native English-speaking teachers to deliver the courses based on their academic expertise in different modules, as was recommended by previous ESP/EAP instruction for Chinese master students (Cargill et al, 2012, Shi, 2018b). Meanwhile, in-service training for language teachers needs to be addressed either by teachers' individual initiatives or by collaborative schemes engaged by subject faculty, professional experts and language teachers (Tao and Gao, 2018; Shi, 2018b).

Finally, teaching administration for MPAcc program should take account of the pressing issues unveiled in this study, and give multiple stakeholders fair consideration in devising and administrating the program, in close collaboration with faculty of language and subject disciplines.

To conclude, business English instruction is an inter-disciplinary ESP-based undertaking (Bargiela-Chiappini \& Zhang, 2013; Shi, 2018b) that needs faculty from different disciplines to design and implement the syllabus with an integrated approach in teaching (Zhang, 2007). Business English for MPAcc candidates designed to widen their international vision needs to be aligned with the learners' needs in teaching contents, and course delivery needs to comply with the physical requirements for language teaching activities.

The study addressed the learning needs of master students, concerns over the course delivery and changes to be made about one business English course for master students in accounting program, which has just explored limited aspects language skills and course contents, and is thus by no means exhaustive. Further empirical studies over wider sampled learners in different disciplines are recommended to design and evaluate ESP-based language courses.

\section{Acknowledgement}

This study is part of the research findings from the project titled The Reform and Innovation of English Programs for Postgraduate Students in CUFE sponsored by Central University of Finance and Economics (Grant Code: KCSZ201810) to whom I extend my thanks.

\section{References}

Bargiela-Chiappini, F., \& Zhang, Z. (2012). Business English. The handbook of English for specific purposes. John Wiley \& Sons, Ltd. https://doi.org/10.1002/9781118339855.ch10

Cai, J. (2004). ESP and the direction of China's college English teaching. Foreign Language World, 2(3), 22-28.

Cargill, M., O' Connor, P., \& Li, Y. (2012). Educating Chinese scientists to write for international journals: Addressing the divide between science and technology education and English language teaching. English for Specific Purposes, 31(1), 60-69. http://dx.doi.org/10.1016/j.esp.2011.05.003

Cheng, A. (2016). EAP at the tertiary level in China: Challenges and possibilities. In K. Hyland, \& P. Shaw (Eds.), The Routledge handbook of English for academic purposes (pp. 97-108). New York: Routledge. https://doi.org/10.1016/j.jslw.2016.10.001

Cheng, A., \& Anthony, L. (2014). ESP research in Asia: Guest editorial. English for Specific Purposes, 33, 1-3. http://dx.doi.org/10.1016/j.esp.2013.07.002

Editing Group of Graduate School English Teaching Syllabus for Non-English Majors. (1993). Graduate School English Teaching Syllabus for Non-English Majors. Chongqing: Chongqing University Press.

Edwards, N. (2000). Language for business: effective needs assessment, syllabus design and materials preparation in a practical ESP case study. English for Specific Purposes, 19(3), 291-296. http://dx.doi.org/10.1016/S0889-4906(98)00029-5

Hutchinson, T., \& Waters, A. (1987). English for Specific Purposes-A learning-centered approach. Cambridge: Cambridge University Press. https://doi.org/10.1017/CBO9780511733031 
Jordan, R. R. (1984). Motivation in ESP: a case study of methods and materials for Economics. In G. James (Ed.), The ESP classroom: methodology, materials, expectations. Exeter Linguistic Studies, 7, 82-88. UK: A. Wheaton \& Co. Ltd., Exeter.

Ku, H., \& Zussman, A. (2010). Lingua franca: The role of English in international trade. Journal of Economic Behavior \& Organization, 75(2), 250-260. https://doi.org/10.1016/j.jebo.2010.03.013

Lee, J. J. (2009). Size matters: an exploratory comparison of small-and large-class university lecture introductions. English for Specific Purposes, 28(1), 42-57. https://doi.org/10.1016/j.esp.2008.11.001

Lu, X., Zhou, W., \& Zhao, Q. (2015). Reform and Development of Professional Degree Education in China. Procedia-Social and Behavioral Sciences, 174, 1379-1385. https://doi.org/10.1016/j.sbspro.2015.01.762

Meng, Y., Yuan, Ch., Liu, J., \& Zhu, J. (2013). Integrating action learning with accounting knowledge in the master degree program for advanced accounting professionals: a case of MPAcc program in CUFE. Academic Degrees \& Graduate Education, 12, 12-16. https://doi.org/10.16750/j.adge.2013.12.007

Serafini, E. J., Lake, J. B., \& Long, M. H. (2015). Needs analysis for specialized learner populations: Essential methodological improvements. English for Specific Purposes, 40, 11-26. http://dx.doi.org/10.1016/j.esp.2015.05.002

Shi, W. (2018a). Exploring course design for a university-level ESP- based College English Program in University of Finance and Economics in China. Journal of Teaching English for Specific and Academic Purposes, 6(1), 115-124. http://dx.doi.org/10.22190/JTESAP1801115S

Shi, W. (2018b). The Essential Issues of the ESP Classroom from a Reflective View. English Language Teaching, 11(6), 16-22. http://dx.doi.org/10.5539/elt.v11n6p16

Tao, J., \& Gao, X. (2018). Identity constructions of ESP teachers in a Chinese university. English for Specific Purposes, 49, 1-13. http://dx.doi.org/10.1016/j.esp.2017.09.003

Taillefer, G. F. (2007). The professional language needs of Economics graduates: Assessment and perspectives in the French context. English for Specific Purposes, 26(2), 135-155. http://dx.doi.org/10.1016/j.esp.2006.06.003

Wang, W. (2015). Teaching English as an international language in China: Investigating Chinese University teachers' and learners' attitude towards China English. System, 53, 60-72. http://dx.doi.org/10.1016/j.system.2015.06.008

Wang, X., \& Yang, L. (2012). Problems and strategies in learning to write a thesis proposal: A study of six MA students in a TEFL program. Chinese Journal of Applied Linguistics, 35(3), 324-41. http://dx.doi.org/10.1515/cjal-2012-0024

Wu, H., \& Badger, R. G. (2009). In a strange and uncharted land: ESP teachers' strategies for dealing with unpredicted problems in subject knowledge during class. English for Specific Purposes, 28(1), 19-32. http://dx.doi.org/10.1016/j.esp.2008.09.003

Zhang, Z. (2007). Towards an integrated approach to teaching Business English: A Chinese experience. English for Specific Purposes, 26, 399-410. http://dx.doi.org/10.1016/j.esp.2006.10.006

China National MPAcc Education Steering Committee. (2014). Guiding syllabus for Master of Professional Accounting in China. Retrieved from http://www.mpacc.cn/displaynews.php?id=1108

\section{Notes}

Note 1 . The averaged ranking (AR) for any principal motivation is obtained from the aggregate of the individual motivation's percentage times its corresponding serial number, the equation applies to Table 6 and 7 .

Note 2. CET-4/6 refers to College English Test Band 4 and 6 that are nation-wide English proficiency tests mandatory for undergraduate students in China's colleges and universities. 